\title{
Immunization, sensibility, and the ressentiments of finance
}

\section{Ute Tellmann}

Technical University of Darmstadt, Germany

It has often been noted that social media and their platforms enable xenophobic sentiments and fake news to 'go viral' while extending surveillance and data mining. ${ }^{1}$ While political pessimism about the current state of democracy might be understandable, the task of understanding is unfinished. What are the relations between digital infrastructure, the data economy, and the 'political regression' of the public sphere (Habermas, 2021)? In his new book, Capital and Ressentiment, Joseph Vogl (2021) argues that the drive belt between these elements is a particular fusion of finance and information economy. He sets out to show how the common genealogies of financialization and digital platform economies engender an affective economy of ressentiment that determines our current political culture.

Ressentiment has a history. As Vogl points out, it emerges at the end of the nineteenth century, at a time when financial techniques and imperial reach became dominant forces in what historians call the first wave of globalization. Vogl defines ressentiment as a constant drive to evaluate and devaluate, a desire to find someone guilty, and a protective emotional gear against what Adorno probably would have called the 'priority of the object' (Adorno, 1966). But the point of Vogl's argumentative tour-de-force is not a historical-cultural reading of the subject of capitalism. Rather, he seeks to show how an economy of affect belongs to what I would call an invisible political infrastructure that links the digital and financialized data economy. Such a political infrastructure works above and below, beside and through the use of social media, apps, or payment structures. It produces an alchemy of effects or rather, affects. The preoccupation of Vogl's book is not ressentiment per se, but its infrastructural production.

Foucault once said that power works upon the subject by establishing an asymmetrical relation of visibility. Vogl seems to say that not only has this asymmetry reached unprecedented heights in the infrastructural abode of finance and information. Also, there is a novel invisibility of these structures that requires a different understanding of power, knowledge, and subjectivation than Foucault has offered so far. Reading the surfaces of discourse and the governmental technologies from documents will no longer do the job. Neither a biopolitics of population nor liberal responsibilization of subjects addresses the field of money and data sufficiently.

\section{Corresponding author:}

Ute Tellmann, Institute of Sociology, Technical University of Darmstadt, Dolivostraße 15, 64293 Darmstadt, Germany. Email: tellmann@ifs.tu-darmstadt.de. https://doi.org/10.2218/finsoc.v7i2.6638 
The work of complementing, reworking, and amending Foucauldian perspectives in order to understand financialization has already characterized Vogl's previous and highly acclaimed book, The Ascendancy of Finance (2017, originally published in 2015). In this earlier book, Vogl uses a Foucauldian framework in order to re-describe the nexus between politics and finance in terms of a particular type of power that he calls seignoral power. Following a Foucauldian perspective, Vogl challenges the notion of a unitary state actor that is overrun by a world of finance. Instead, he detects a 'zone of indeterminacy' between sovereignty and money, between public and private, between state and market. In this zone, the private creation and management of money on the one hand, and its public valuation and legal protection on the other, enter into a tight coupling above and beyond the narratives of modern liberal differentiation between politics and economy (Tellmann, 2017). Going against Foucault's owns inclinations, Vogl emphasizes that this zone of indeterminacy is characterized by sovereign enclaves of exception - finance is protected by the sovereign powers of the state while simultaneously hollowing them and displacing them. Sovereignty and exception become central categories for fitting a Foucauldian analytics of power to this shadowy zone of indifference between the public and the private.

In Capital and Ressentiment (2021), Vogl sets out to map another zone of indeterminacy: this time, a convergence of financial markets, notions of information, digital infrastructure, public actors, and economies of data. Through an extremely convincing cross-over between a genealogy of digital infrastructures and a genealogy of financialization, Vogl shows that their point of convergence is an operational account of information. Information is conceptually distinguished from knowledge. The latter is always defined by regimes of proof and justification, whereas the former exists in disregard of such content-related procedures. Information is something else - a quasi-currency that turns markets and publics into homologous spheres that are trading with trends of opinion.

In contrast to his previous book, Vogl does not focus on the question of political rationality or technologies of power per se. The question of control, algorithm, and protocol sublates these Foucauldian preoccupations. He prominently refers to the political reading of such technical protocols (Galloway, 2004). Protocols are a technical, executive form of patterning, hierarchizing, and channeling information. There seems to be no gap anymore - not even internally - between the reality governed and the modes of governing. Data only exists as produced and governed. Reality becomes 'capitalist ontology'. While technical mediation of such dataifcation is more extensive than ever, the experience of it is more immediate than ever. What is the anatomy of power that thrives on such an asymmetry of visibility (or asymmetry of immediacy)?

Vogl himself invites such questions but he does not ponder them systematically or in depth. The themes of sovereignty and exception that Vogl laid out in his previous book remain present, but they are not foregrounded. At the same time, the pessimistic tone of the book makes questions of power, political rationalities, and technologies even more intriguing.

In my remaining commentary I would like to mobilize the themes, inspirations, and loose threads laid out by Vogl's books for addressing this Foucauldian question regarding the anatomy of power. At the center of my reading is a notion that Vogl introduces only in passing: immunity. Both books make use of this concept without ever defining it or dwelling extensively on it. But if one follows how immunity is introduced and used, sparingly as it is, a conceptual pattern emerges. When using it, Vogl always points at a combination of a heightened sensibility on the one hand, and an absconding of societal, legal, or public obligation on the other. I want to argue that this notion of immunity can help to understand the anatomy of power that is at work in both zones of indeterminacy that Vogl has explored in his two books. 
Today we understand immunity mostly in the context of health and bodily integrity. Especially in the context of the ravaging pandemic, immunity raises associations with population, public health, infections, viruses, and bodies. But its etymology is political. Immunity in Roman law referred to the specific political status of being not-bound or unbound by obligations. In Roman law, immunity meant being exempted from the duty to pay taxes and conscription. It is the exception from the obligation that would regularly pertain to all citizens (Cohen, 2009; Esposito, 2004: 13). In The Ascendancy of Finance, Vogl refers to the selectively organized immunity that he associates with sovereignty. In relation to privately organized monetary powers, the political sovereign might be granted financial immunity when he does not have to pay his debt - but only insofar as the monetary power is rendered even more immune to obligations, that is, more sovereign than the state itself. Moreover, the political sovereign becomes selectively immunized or sensibilized to different publics: interplay between political sovereignty and private provision of currencies results in a heightened sensibility to financial publics and an immunity against political publics.

In Capital and Ressentiment, Vogl seems to detect an analogical coupling of immunity and sensibility - sometimes using these words, sometimes not. He points out that the data economy of digital platforms depends on an extreme sensibility to any trace that a user has left behind. Any communicative act, any movement or utterance in everyday life, becomes an event that is turned into new patterns, customized advertisements, and new business models. But this heightened sensibility is coupled with a decisive immunity against the claims raised from or the obligations to that side. Platforms offer services and goods, but are shielded from the wear and tear of this world of service, care, and production. They are also rendered immune, that is they are legally unbound, from the obligation to expose the modes of extracting, channeling, and using the data they mine. In other words, they are immune from public quests and duties, from care and production, while thriving on extreme access and sensitivity to traces and patterns in data. This selective combination of knowing and ignorance, visibility and intransparency, use and disregard, exposes this anatomy of power.

The making and unmaking of immunity is ill-understood if one operates with the notions of sovereignty-as-exception that Vogl developed in The Ascendancy of Finance. It is not just the sovereign exception that matters, but the legal, political, moral, and technical combination of being immunized and sensitized in different respects. Further work is required in order to understand how this novel 'distribution of the sensible' (Rancière) and 'distribution of the obligatory' takes place. "Devices of obligation”, as I have called them, embroil materiality, morality, law, and politics in order to produce financial security (Tellmann, 2021b; see also Boy and Gabor, 2019). Hence, the calibrations of visibility and invisibility, sensibility and insensibility, obligation and immunity that Vogl lays bare do not exist just as exceptions from law, but are part of prevailing legal-political conditionalities (Pistor, 2019). The role of such legal-political devices needs to be further studied in fields such as cultural economy, political theory, and sociology. Vogl maps these zones of indeterminacy with great insight, attuned to the politics of our time. Capital and Ressentiment is a book to think with.

\section{Notes}

1. A related review appeared in German in Behemoth: A Journal on Civilisation, as part of a special issue on 'Sovereignty of the Platform', edited by Jonas Heller and Marina Martinez Mateo (Tellmann, 2021a). All references are to Kapital und Ressentiment (Vogl, 2021). An English translation of the book will be published by Polity Press next year as Capital and Ressentiment (Vogl, 2022). 


\section{References}

Adorno, T.W. (1966) Negative Dialektik. Frankfurt a.M.: Suhrkamp.

Boy, N. and Gabor, D. (2019) Collateral times. Economy and Society, 48(3): 295-314.

Cohen, E. (2009) A Body Worth Defending: Immunity, Biopolitics, and the Apotheosis of the Modern

Body. Durham, NC: Duke University Press.

Esposito, R. (2004) Immunitas: Schutz und Negation des Lebens. Berlin: Diaphanes.

Galloway, A. (2004) Protocol: How Control Exists After Decentralization. Cambridge, MA: MIT Press.

Habermas, J. (2021) Überlegungen und Hypothesen zu einem neuen Strukturwandel der Öffentlichkeit. In: Seeliger, M. and Sevigni, S. (eds.) Ein neuer Strukturwandel der Öffentlichkeit: Leviathan

Sonderband 37. Baden-Baden: Nomos Verlagsgesellschaft, 470-500.

Pistor, K. (2019) The Code of Capital: How the Law Creates Wealth and Inequality. Princeton, NJ: Princeton University Press.

Riles, A. (2011) Collateral Knowledge: Legal Reasoning in the Global Financial Markets. Chicago, IL: University of Chicago Press.

Tellmann, U. (2017) Life and Money: The Genealogy of the Liberal Economy and the Displacement of Politics. New York: Columbia University Press.

Tellmann, U. (2021a) Immunisieren-Über die politischen Praktiken der digitalen Finanzökonomie. Kommentar zu Joseph Vogl: Kapital und Ressentiment im Spiegel des Souveränitätseffekts.

Behemoth: A Journal on Civilisation, 14(1): 30-35.

Tellmann, U. (2021b) The politics of assetization: From devices of calculation to devices of obligation. Distinktion: Journal for Social Theory, forthcoming.

Vogl, J. (2015) Der Souveränitätseffekt. Zürich: Diaphanes.

Vogl, J. (2017) The Ascendancy of Finance, translated by S. Garnett. Cambridge: Polity.

Vogl, J. (2021) Kapital und Ressentiment: Eine kurze Theorie der Gegenwart. München: C.H. Beck.

Vogl, J. (2022) Capital and Ressentiment, translated by N. Solomon. Cambridge: Polity. 